\title{
HUBUNGAN ANTARA KADAR HEMOGLOBIN IBU HAMIL TRIMESTER III DENGAN BERAT BADAN JANIN DI PUSKESMAS TRAUMA CENTER SAMARINDA
}

\author{
Relationship Between Hemoglobin Level Iii Trimester Pregnant Women With Fetal Weight In \\ Trauma Center Health Samarinda
}

\author{
Tri Wahyuni ${ }^{1}$,Rina Ayu Hanna ${ }^{2}$ \\ ${ }^{1}$ Dosen Prodi Ilmu Keperawatan Fakultas Ilmu Kesehatan UMKT \\ ${ }^{2}$ Mahasiswa Prodi Ilmu Keperawatan Fakultas Ilmu Kesehatan UMKT
}

\begin{abstract}
ABSTRAK
Latar Belakang : Hemoglobin adalah parameter yang digunakan secara luas untuk menetapkan prevalensi anemia. Anemia pada ibu hamil akan menambah resiko mendapatkan Bayi Berat Lahir Rendah (BBLR), resiko perdarahan sebelum dan pada saat persalinan bahkan akan menyebabkan kematian ibu dan bayinya jika ibu hamil tersebut menderita anemia berat. World Health Organization (WHO) merekomendasikan kadar Hemoglobin ibu hamil ideal adalah lebih dari 11 gr/dl. Tinggi rendahnya kadar Hemoglobin ibu hamil selama kehamilan mempunyai pengaruh terhadap berat bayi lahir karena dapat mengakibatkan gangguan pertumbuhan janin di dalam kandungan.

Tujuan : penelitian ini bertujuan untuk mengetahui hubungan kadar Hemoglobin ibu hamil trimester III dengan berat badan janin di Puskesmas Trauma Center Samarinda.

Metode : Penelitian ini adalah deskritif korelasional dengan pendekatan time series. Populasi penelitian ini adalah selurus ibu hamil trimester III yang terdata dan memeriksakan kehamilannya di Puskesmas Trauma Center yang sesuai kriteria inklusi mulai dari bulan mei sampai juli 2017. Pengambilan sampel pada penelitian ini dengan metode total sampling dengan jumlah sampel sebanyak 39 orang. Instrument penelitian menggunakan lembar observasi. Data yang terkumpul dianalisis dengan teknik analisa univariat (median dan distribusi frekuensi) dan teknik analisa bivariate dengan uji chi square.

Hasil Penelitian : Didapatkan bahwa ada hubungan yang bermakna antara kadar hemoglobin ibu hamil trimester III dengan berat badan janin di Puskesmas Trauma Center dengan nilai Pvalue $=0,000$.

Kesimpulan : karakteristik responden penelitian di Puskeamas Trauma Center yaitu sebagian besar responden berada dalam kelompok usia 20-35 tahun yaitu sebanyak 33 orang (84.6\%) sebagian besar responden berpendidikan SMA yaitu sebanyak 19 orang $(48.7 \%)$, sebagian besar responden adalah ibu rumah tangga yaitu sebanyak 26 orang $(66.7 \%)$ sebagian besar responden kehamilan kedua atau lebih (multigravida) yaitu sebanyak 23 orang $(59.0 \%)$ sebagian besar responden memiliki kadar Hemoglobin normal sebanyak 24 orang $(61.5 \%)$ dan sebagian besar responden memiliki bayi dengan berat badan normal sebanyak 21 orang (53.8\%). Ada hubungan kadar Hemoglobin ibu hamil trimester III dengan berat badan janin di Puskesmas Trauma Center samarinda dengan nilai $\mathrm{P}$-value $=0.000$ di peroleh pula nilai $\mathrm{OR}=70,000$.
\end{abstract}

Kata kunci : kadar Hemoglobin ibu hamil trimester III, berat badan janin.

\section{ABSTRACT}

Background: Hemoglobin is a widely used parameter to define the prevalence of anemia. Anemia in pregnant women will increase the risk of getting Infant Low Birth Weight (LBW), the risk of bleeding before and during delivery will even cause the death of the mother and baby if the mother is suffering from severe anemia. World Health Organization (WHO) recommends pregnant women ideal Hemoglobin levels were more than $11 \mathrm{~g} / \mathrm{dl}$. High and low levels of hemoglobin of pregnant women during pregnancy has an effect on birth weight because it can lead to impaired fetal growth in the womb. 
Objective: This study aimed to determine the relationship of the levels of Hemoglobin third trimester pregnant women with fetal weight in PHC Trauma Center Samarinda.

Methods: This study is a descriptive correlationalapproach to time series. The study population was selurus third trimester pregnant women were recorded and checkups in Health Center Trauma Center corresponding inclusion criteria starting from the month of May to July 2017. The sample in this study with amethod total sampling with a total sample of 39 people. Instrument research using observation sheet. The collected data were analyzed by using univariate analysis (median and frequency distribution) and bivariate analysis techniques withtest. chi square

Results: It was found that there was a significant correlation between hemoglobin level third trimester pregnant women with fetal weight in PHC Trauma Center with P-value $=0.000$.

Conclusion: respondent characteristics in Puskeamas Trauma Center study that most of the respondents were in the age group 20-35 years as many as 33 people (84.6\%) are mostly high school-educated respondents as many as 19 people (48.7\%), most respondents were housewives as many as 26 people (66.7\%), most respondents second pregnancy or more (multigravida) as many as 23 people (59.0\%), most of the respondents had higher levels of hemoglobin to normal as many as 24 people (61.5\%) and the majority of respondents have a baby of normal weight 21 persons (53.8\%). There is a relationship Hemoglobin levels of third trimester pregnant women with fetal weight in PHC Trauma Center samarinda with P-value $=0,000$ in obtaining the value of OR = 70,000 .

Keywords: Hemoglobin levels of third trimester pregnant women, fetal weight.

\section{PENDAHULUAN}

Kematian ibu menurut definisi Worid Health Organization (WHO) adalah kematian selama kehamilan atau dalam periode 42 hari setelah berakhirnya kehamilan, akibat semua sebab yang terkait dengan atau diperberat oleh kehamilan atau penanganannya, tetapi bukan disebabkan oleh kecelakaan atau cidera. World Health Organization (WHO) pada tahun 2012, melaporkan bahwa prevalensi anemia pada ibu hamil di Dunia berkisar rata-rata 41,8\%. Hasil Riset Kesehatan Dasar (Riskesdas) pada tahun 2013, prevalensi ibu hamil dengan anemia di Indonesia sebesar 37,1\%. Menurut Sistem Kesehatan Nasional (SKN) tahun 2012 angka ibu hamil dengan anemia di Indonesia yaitu sebesar $40 \%$.

Kehamilan merupakan bagian dari tahap kehidupan atau siklus hidup seorang wanita atau tantangan perkembangan yang harus dihadapi seluruh anggota keluarga, khususnya bagi calon ibu seperti perubahan citra tubuh, perubahan hormonal, bahkan ketidaknyamanan diberbagai aspek fisiologis dan psikologis (Bartini, 2012).

Kadar $\mathrm{Hb}$ ibu hamil terjadi jika produksi sel darah merah meningkat, nilai normal hemoglobin (12 sampai $16 \mathrm{gr} / \mathrm{dl}$ ) dan nilai normal hematokrit (37\% sampai 47\%) menurun secara mencolok. Penurunan lebih jelas terlihat selama trimester kedua, saat terjadi ekspansi volume darah yang cepat. Apabila nilai hematokrit turun sampai $35 \%$ atau lebih, wanita dalam keadaan anemia (Wang J dkk, 2007).

Berat bayi lahir sebagai salah satu indikator kesehatan bayi baru lahir. Berat bayi lahir normal (usia gestasi 37 sampai 42 minggu) adalah 2.500 sampai 4.000 gram. Berat bayi lahir normal merupakan suatu hal yang sangat penting karena akan menentukan kemampuan bayi untuk dapat menyesuaikan diri terhadap lingkungan hidup yang baru sehingga tumbuh kembang bayi akan berlangsung secara normal. BBLR merupakan salah satu dampak tidak sempurnanya tumbuh kembang janin selama di dalam rahim ibu. BBLR adalah bayi yang mempunyai berat lahir kurang dari 2.500 gram yang ditimbang pada saat lahir sampai dengan 24 jam pertama setelah lahir. BBLR mempunyai resiko morbiditas dan mortalitas yang tinggi (Damanik SM, 2010)

\section{METODOLOGI PENELITIAN}

Penelitian ini menggunakan penelitian deskritif korelasional yang bertujuan untuk mengungkapkan hubungan korelasi antara variabel yaitu hubungan antara kadar hemoglobin ibu 
hamil dengan berat badan janin di Puskesmas Trauma Center, dengan pendekatan time series ialah studi untuk mengetahui hubungan komparatif beberapa subjek yang diteliti.

Time Series lebih menekankan pada data penelitian berupa data rentetan waktu.

Sampel pada penelitian ini terdapat 39 ibu hamil trimester III di Puskesmas Trauma Center. Adapun teknik penentuan sampel yang digunakan dalam penelitian ini dengan menggunakan teknik total sampling. Waktu penelitian ini dilaksanakan pada tanggal 5 Mei sampai 29 Juli 2017.

Dalam penelitian ini peneliti mengunakan instrument berupa lembar observasi yang disusun sendiri oleh peneliti, timbangan dimana sebelum digunakan akan dipastikan akurasinya melalui kalibrasi dan Haemometer.

HASIL DAN PEMBAHASAN

Tabel 4.5 Karakteristik responden berdasarkan kadar $\mathrm{Hb}$ ibu hamil trimester III di Puskesmas Trauma Center Samarinda

\begin{tabular}{ccc}
\hline Kadar Hb & Frekuensi & Presentase (\%) \\
\hline Normal & 24 & 61.5 \\
Anemia ringan & 15 & 38.5 \\
\hline Total & 39 & 100.0
\end{tabular}

Sumber : Data primer 2017

Berdasarkan tabel 4.5 diketahui bahwa responden yang memiliki kadar $\mathrm{Hb}$ normal sebanyak 24 orang $(61.5 \%)$ dan responden dengan anemia ringan sebanyak 15 orang $(38.5 \%)$.

Hemoglobin adalah protein majemuk yang tersusun atas protein sederhana yaitu globin dan radikal prostetik yang berwarna, yang disebut heme. Protein ini terdapat dalam butir-butir darah merah dan dapat dipisahkan dari padanya dengan cara pemusingan. Berat molekulnya yang ditentukan dengan ultrasentrifuge sebesar 68.000. Ini adalah protein pertama yang diperoleh dalam bentuk hablur. Hemoglobin merupakan protein pembawa oksigen dalam darah. Tiap liter darah mengandung kira-kira 150 gr hemoglobin (Damin Sumardjo, 2009).

Pada ibu hamil yang kadar Hbnya tidak normal, dapat disebabkan karena kekurangan makanan yang mengandung zat besi, asam folat dan vitamin B12 seperti hati, ikan teri, daging merah, kacang-kacangan, sayuran bewarna hijau, kuning telur dan buah-buahan. Jumlah darah yang ada terpakai untuk kebutuhan ibu dan janin, volume darah jadi berkurang pada awal kehamilan sampai trimester III, terjadi tekanan darah rendah yang disebakan karena terjadinya peningkatan plasma darah, terjadi penambahan cairan tubuh (Volume plasma) yang tidak sebanding dengan penambahan massa sel darah merah, akibatnya kadar hemoglobin menurun. Penurunan kadar $\mathrm{Hb}$ pada wanita sehat yang hamil disebabkan ekspansi volume plasma yang lebih besar daripada peningkatan volume sel darah merah dan hemoglobin. Kadar $\mathrm{Hb}$ ibu hamil yang tidak normal sangat mempengaruhi pertumbuhan dan perkembangan janin. Ibu hamil dianjurkan untuk memeriksakan kehamilannya minimal 4 kali terutama pemeriksaan kadar $\mathrm{Hb}$ trimester I dan trimester III karena terjadi pengenceran darah. Kadar $\mathrm{Hb}$ tidak normal yaitu kadar $\mathrm{Hb}$ kurang dari 11g/dl pda trimester pertama dan trimester ketiga, dan kurang dari 10,5g/dl pada trimester kedua (Proverawati, 2009).

Berdasarkan uraian di atas peneliti berasusmi bahwa kadar $\mathrm{Hb}$ ibu hamil trimester III mempengaruhi pertumbuhan dan perkembangan janin dan dapat menyebabkan anemia pada ibu karena pada ibu hamil trimester III janin akan menimbun banyak zat besi untuk persiapan pada 1 bulan pertama kelahirannya.

Tabel 4.6 Karakteristik responden Berdasarkan Berat Badan janin di Puskesmas Trauma Center Samarinda

\begin{tabular}{ccc}
\hline Berat badan janin & Frekuensi & Presentase (\%) \\
\hline Normal & 21 & 53.8 \\
Rendah & 18 & 46.2 \\
\hline Total & 39 & 100.0
\end{tabular}

Sumber : Data primer 2017

Berdasarkan pada tabel 4.6 diatas diperoleh gambaran bayi dengan berat badan bayi lahir normal sebanyak 21 bayi (53.8\%) dan berat badan lahir rendah sebanyak 18 bayi (46.2\%). 
Pertumbuhan janin dalam kandungan merupakan hasil interaksi antara potensi genetik dari ayah maupun ibu dan lingkungan intrauteri. Pertumbuhan janin di pengaruhi oleh faktor-faktor selama kehamilan, yaitu sakit berat, komplikasi kehamilan, kurang gizi, dan keadaan stress pada ibu hamil (Soetjiningsih, 2012).

Hingga saat ini di Indonesia sudah terdapat beberapa penelitian yang mencoba untuk mencari hubungan antara kadar hemoglobin ibu hamil dengan berat bayi lahi. Suatu penelitian Cohort prospective di kota semarang saat trimester III kehamilan menemukan bahwa terdapt hubungan yang bermakna antara kadar $\mathrm{Hb}$ ibu hamil dengan berat bayi lahir. Trimester III kehgamilan memang merupakan masa dimana terjadinya pertumbuhan janin yang lebih cepat dibandingkan trimester sebelumnya (Fidranti DY, 2007).

Berdasarkan uraian diatas peneliti berasumsi berat badan lahir normal adalah berat lahir lebih dari 2.500 gram bayi dilahirkan setelah dikandung 37 sampai 42 minggu massa gestasi. Berat bayi normal merupakan suatu hal yang sangat penting karena akan menentukan kemampuan bayi untuk menyesuaikan diri terhadap lingkungan yang baru sehingga tumbuh kembang janin dapat berlangsung secara normal.

Tabel 4.7 Hasil Bivariat kadar Hb ibu hamil trimester III dengan berat badan janin di Puskesmas Trauma Center Tahun 2017.

\begin{tabular}{|c|c|c|c|c|c|c|c|c|}
\hline \multirow[t]{2}{*}{ Variabel } & \multicolumn{4}{|c|}{ Berat Badan Janin } & \multicolumn{2}{|c|}{ Total } & $\mathrm{p}$ Value & OR \\
\hline & \multicolumn{2}{|c|}{ Normal } & \multicolumn{2}{|c|}{ Rendah } & & & \multirow{5}{*}{0.000} & \multirow{5}{*}{$\begin{array}{c}70,000 \\
(7.051- \\
694.901)\end{array}$} \\
\hline Kadar $\mathrm{Hb}$ & $\mathrm{n}$ & $\%$ & $\mathrm{n}$ & $\%$ & $\mathrm{~N}$ & $\%$ & & \\
\hline Normal & 20 & 83.3 & 4 & 16.7 & 24 & 100 & & \\
\hline Anemia ringan & 1 & 6.7 & 14 & 93.3 & 15 & 100 & & \\
\hline Jumlah & 21 & 53.8 & 18 & 46.2 & 39 & 100 & & \\
\hline
\end{tabular}

Berdasarkan hasil analisis dari tabel 4.7 diatas tentang kadar $\mathrm{Hb}$ ibu hamil trimester III dengan berat badan janin di Puskesmas Trauma Center dari 24 responden, yang memiliki kadar Hb normal 20 responden $(83.3 \%)$ yang berat badan janinnya normal, dan 4 responden $(16.7 \%)$ yang berat badannya rendah. Dari 15 responden dengan anemia ringan sebanyak 1 responden $(6.7 \%)$ yang memiliki berat badan janin normal, dan 14 responden (93.3\%) yang memiliki berat badan janin rendah.

Hasil uji statistik diperoleh hasil $\mathrm{P}$ value $0.000<\alpha(0.05)$ sehingga dapat dinyatakan hipotesis nol ditolak dan menerima hipotesis alternatif yang mengatakan terdapat hubungan bermakna antara kadar $\mathrm{Hb}$ ibu hamil trimester III dengan berat badan janin. Nilai OR dengan CI (95\%) (7.051 694.901) yang berarti responden yang memiliki $\mathrm{Hb}$ normal memiliki peluang 70,000 kali untuk memiliki berat badan janin normal dibandingkan dengan responden yang anemia ringan memiliki berat badan janin rendah.

Hubungan kadar $\mathrm{Hb}$ trimester III dengan berat bayi lahir memng telah dilaporkan pada beberapa penelitian. Kadar $\mathrm{Hb}$ ibu hamil trimester III yang rendah dan tinggi dapat mengakibatkan pentumbuhan janin terhamat/kecil untuk masa kehamilan (Wang J,dkk, 2008).

Berdasarkan hasil penelitian pada tabel 4.7 terdapat 4 responden yang memiliki kadar $\mathrm{Hb}$ normal tetapi berat badan janinnya rendah hal ini dikarenakan asupan nutrisi selama hamil kurang tercukupi dan kenaikan berat badan ibu selama hamil kurang dari $9 \mathrm{~kg}$ dan terdapat satu bayi dengan berat badan lahir rendah dari ibu yang anemia ringan setelah di kaji asupan nutrisi ibu cukup baik dan kenaikan berat badan ibu selama hamil normal yaitu $9 \mathrm{~kg}$.

Berdasarkan uraian di atas peneliti berasumsi bahwa terdapat hubungan antara kadar $\mathrm{Hb}$ ibu hamil trimester III dengan berat badan janin, dimana apabila ibu hamil kekurangan kadar $\mathrm{Hb}$ menyebabkan darah tidak dapat mengirim cukup banyak oksigen ke seluruh jaringan, sehingga proses metabolisme dan pertukaran zat yang penting dalam jaringan terganggu, sehingga menyebabkan berkurangnya suplai makanan hasil konsepsi melalui plasenta. Akibatnya plasenta menjadi kecil dan transfer gizi ke janin yang diperlukan untuk perkembangan dan pertumbuhan janin berkurang. Kondisi ini menyebabkan lambatnya pertumbuhan janin sehingga berat badan lahir menjadi rendah. 


\section{KETERBATASAN PENELITIAN}

Penelitian ini datanya berupa beberapa subjek pada waktu tertentu. Dalam penelitian ini pegambilan data dari masing-masing variabel di lakukan secara bertahap sehingga memerlukan waktu lama.

\section{KESIMPULAN}

Kesimpulan dari penelitian ini adalah Hasil uji statistik dengan menggunakan Chi square maka diperoleh P Value 0,000 lebih kecil dari $\alpha=0,05$ berarti $\mathrm{H} 0$ ditolak yang berarti ada hubungan yang bermakna antara kadar $\mathrm{Hb}$ ibu hamil trimester III dengan berat badan janin di Puskesmas Trauma Center Samarinda.

\section{SARAN-SARAN}

Hasil penelitian ini dapat digunakan sebagai referensi untuk penelitian selanjutnya tentang berat badan janin, dengan mengangkat faktor-faktor lain. Kepada peneliti lain diharapkan hasil penelitian ini dapat dijadikan acuan untuk melakukan penelitian selanjutnya diharapkan dapat lebih mengali fakor-faktor yang berhubungan dan mempengaruhi berat badan janin sehingga mendapatkan hasil yang lebih komprehensif dan akurat.

\section{KEPUSTAKAAN}

Abdul muthalib, 2010 Kelainan hematologik. Dalam Saifuddin AB, editor : ilmu kebidanan Sarwono Prawirohardjo Edisi keempat. Jakarta :PT Bina Pustaka Sarwono Prawirohardjo,.

Arikunto, S, 2010 . Prosedur Penelitian Suatu Pendekatan Praktek, (edisi revisi) Jakarta : PT. Rineka Cipta.

Asiyah S, Suwoyo dan Mahaendriningtyastuti. Karakteristik bayi berat lahir rendah (BBLR) sampai tribulan II 2009 di kota Kediri. Jurnal Penelitian Kesehatan Suara Forikes 2009.

Atikah, Proverawati. 2011. Anemia dan Anemia Kehamilan. Jakarta : Nuha Medika.

Bartini I, 2012 .Buku Pintar : Panduan dan Tips Hamil Sehat, Nuha Medika: Jogjakarta.

Bobak, dkk. 2004. Buku Ajar Keperawatan Maternitas, Edisi keempat. Komalasari, Renata (penerjemah). Jakarta : EGC.

Budishmily. 2011. Hubungan Tingkat Pendidikan dan Pengetahuan Gizi dengan Status Gizi Ibu Hamil di Desa Bojong Lor Kecamatan Bojong Kabupaten Pekalongan.

Chunningham, F, Gary. 2010. Obstretri Williams, edisi 21, Hartono, Andry, dkk (Penerjemah) Jakarta EGC.

Damanik SM, 2010. Klasifikasi bayi menurut berat lahir dan masa gestasi. Dalam : Kosim MS, Ari Y, Rizalya D, Gatot IS, Ali U. Buku ajar neonatologi. Edisi 1. Jakarta : Ikatan Dokter Anak Indonesia

Damin Sumardjo. 2009. Pengantar Kimia: Buku panduan kuliah Mahasiswa kedokteran dan program Strata I Fakultas Bioeksakta. Jakarta: EGC.

De Benoist, Melean E, Egli, Cogswell M, editor. Worldwide prevalence of anemia 1993-2005 :WHO global database on anemia. Switzerland : WHO Press; 2008.

Departemen Kesehatan RI. 2009, Profil kesehatan Indonesia. Jakarta : Depkes RI.

Dian O, Winarsih S dan Ariani. Analisis faktor-faktor yang mempengaruhi berat badan lahir rendah (BBLR) di RSUD dr. Saiful Anwar Malang periode 1 Januari-31 Desember 2011.

Djamilus, Herlina, 2008, Faktor Risiko Kejadian Anemia Ibu Hamil Di Wilaya Kerja Puskesmas Bogor, Artikel, Available from : http://www. motekar.tk/topik/pengkajian-anemia-pada-ibuhamil.html

Fajrina A, 2011, Hubungan pertambahan Berat Badan Selama Hamil dan faktor lain dengan Berat Badan Lahir, UI, Jakarta.

Fidranti DY. Hubungan pertambahan berat badan, kadar hemoglobin, tingkat asupan asam folat, dan seng ibu hamil pada trimester II dan III dengan berat bayi lahir di puskesmas Ngesrep dan Pandanaran Semarang (artikel penelitian). Semarang : Universitas Diponegoro; 2007.

Hapisah, Dasuki, D, Prabandari, Y.S, 2010. Depressive symptoms pada ibu hamil dan bayi berat lahir rendah. Berita kedokteran masyarakat, vol 26 No 2. 
Hidayat A.A, 2008. Pengantar ilmu kesehatan anak untuk pendidikan kebidanan. Jakarta :Salemba Medika.

Kementrian kesehatan laporan hasil riset kesehatan dasar RIKESDA Indonesia, 2013. Jakarta: Departemen Kesehatan RI.

Kristyanasari, Weni, 2010. Gizi ibu hamil. Nuha Medika. Jakarta.

Lone FW, Qireshi RN, 2008. Emmanuel F. Maternal Anemia and its Impact on Perinatal outcome in a tertiary care hospital in Pakistan. Eastern Mediterranean Health Jornal.

MacDonal MG, SeshiaMM, Mulett MD, 2007 editor. Avery's neonatology 6th editor, USA Lippincott Wiliam \& Wilkins.

Mansjoer, Arif 2008. Kapita selekta kedokteran edisi ketiga jilid pertama, Jakarta: Media Aesculapius. Foster.

Manuaba, IBG, dkk, 2010. Ilmu Kebidanan dan Penyakit Kandungan KB. Jakarta: egc

Mitayani, 2009. Asuhan Keperawatan Maternitas. Jakarta: Salemba Medika.

Mochtar, R. 2010. Synopsis Obstetri. Jakarta EGC.

Muazizah, Nugroho A.H. dan Rahmawati A, 2011. Hubungan Kadar Hemoglobin dengan Berat badan lahir di RS permata bunda Kab. Grobogan Tahun 2011, http:/jurnal.unimus.ac.id. diakses tanggal 18 mei 2016

Notoadmodjo S, 2010. Metode Penelitian Kesehatan Jakarta: Rineka Cipta. , 2012. Metodologi Penelitian Kesehatan. Jakarta : Rineka Cipta.

Nursalam, 2008. Konsep Penerapan Metodologi Penelitian Ilmu Keperawatan. Jakarta: Salemba Medika

, 2011. Konsep dan penerapan metodologi penelitian ilmu keperawatan. Pedoman Skripsi, Tesis, dan Instrumen Penelitian Keperawatan. Edisi 2. Jakarta : Salemba Medika.

Pilliteri, A. 2008. Maternal and cchild Healt Nursing: Care Of The Child Bearing and Childrearing Family. Philadelphi: Lippincot

Prawirohardjo, 2007. Ilmu Kebidanan, Jakarta : Yayasan Bina Pustaka.

Proverawati A, dan Asfuah S, 2009. Buku ajar gizi untuk kebidanan, Nuha Medika, Yogyakarta.

, 2006. Buku panduan praktis pelayanan kesehatan maternal \& neonatal. Jakarta : Yayasan Bina Pustaka.

Rahardjo B, Khasanah U dan Habibah K. Hubungan antara usia ibu dan paritas dengan kejadian berat badan lahir rendah (BBLR) di RSUP dr.Saiful Anwar Malang (periode 1 Januari 201131 Desember 2011).

Rahayu MLD. Pengaruh karakteristik, perilaku dan sosial ekonomi ibu terhadap kelahiran bayi BBLR (berat badan lahir rendah) di kabupaten Sidoarjo. Karya Tulis Ilmiah. Surabaya: Pendidikan Geografi Universitas Negeri Surabaya, 2011.

Ridayanti N.K.A, Lanni F. dan Wahyuningsih M. 2012. Hubungan Tingkat Pendidikan Ibu Hamil Dengan Kejadian Anemia Pada Kehamilannya Di Puskesmas Banguntapan 1 Bantul, Journal.

Riduwan, 2010. Dasar-dasar statistik . Bandung : Alfabeta

Riset Kesehatan Dasar (Riskesdas), 2013, badan penelitian dan pengembangan kesehatan kementrian kesehatan RI. Jakarta.

Riyanto, A 2011, Aplikasi Metodologi Penelitian Kesehatan. Yogyakarta : Nuha Medika.

Rukiyah, A. Y. 2012. Asuhan Kebidanan 4 ( Patologi). Jakarta : Trans Info Media.

Saifuddin, AB, 2006, Buku Acuan Nasional Pelayanan Kesehatan Maternal dan Neonatal, Edisi I Cetakan Keempat, Jakarta ; Yayasan Bina Pustaka Sarwono Prawirohardjo,2006.

Sediaoetama, A. D. 2008. Ilmu gizi untuk mahasiswa dan profesi. Dian Rakyat Jakarta.

Suryani. 2009. Hubungan Pengetahuan dan Status Ekonomi dengan Status Gizi Ibu Hamil di Puskesmas Putri Ayu Kota Jambi.

, 2008 Rachimhadi T, Wiknjosastro GH. Ilmu Kebidanan Edisi 4. Jakarta : PT. Bina Pustaka Sarwono Prawirohardjo.

Soebroto, Ikhsan.2009, Cara Mudah Mengatasi Problem Anemia, Yogyakarta: penerbit, Bangkit. Sugiyono. 2010. Metodologi Penelitian Kuantitatif, Kualitatif dan R dan D. Bandung penerbit Alfabet.

Sulistyoningsih. 2011, gizi untuk kesehatan ibu dan anak. Yogyakarta, Graha ILmu. 
Sumanto. 2014. Teori dan Aplikasi Metode Penelitian . Yogyakarta: CAPS.

Supariasa, I.D.N, 2012, penelitian status Gizi. Jakarta: EGC.

Yuliva, Ismail, D, 2009. Hubungan status pekerjaan ibu dengan berat lahir bayi di RSUP dr.M.Djamil Padang

Varney Hellen, M.Kriebs Jam. 2008. Buku Ajar Asuhan Kebidanan :2 Penerbit Buku Kedokteran EGC: Jakarta.

Wang J dkk. 2007. Study on the third trimester hemoglobin concentrations and the risk of low birth weight and preterm delivery. PubMed.

Wasis. 2008 .Pedoman Riset Praktis Untuk Profesi Perawat. Jakarta :EGC

WHO. 2012. Daily Iron and Folic Acid Supplement in Pregnant Women. In W.H Organization (Ed). Geneva.

Wiknjosastro, Hanifa. 2007. Ilmu Kebidanan Edisi ketiga. Jakarta, Yayasan Bina Pustaka Sarwono Prawirohardjo. 